\title{
Knowledge, Attitudes and Practices of the Population of the District of Ahomadégbé (Municipality of Lalo) in Benin on Methods of Water Treatment at Home
}

\author{
Hermione Amoukpo1*, Zoulkifl Salou Bachirou1, Gabriel Diez², Larys Akuesson1, \\ Rachad Lanignan1, Horace Degnonvi'1, Yves Barogui³, Gratien Boni1 ${ }^{1}$ Michel Boko', \\ Roch Christian Johnson ${ }^{1}$
}

\begin{abstract}
${ }^{1}$ Laboratory of Hygiene, Sanitation, Toxicology and Environmental Health, Interfaculty Center of Training and Research in Environment for the Sustainable Development (CIFRED), University of Abomey-Calavi (UAC), Cotonou, Benin

${ }^{2}$ Anesvad Foundation, General Concha, Bilbao, Spain

${ }^{3}$ National Buruli Ulcer Control Program, Ministry of Health, Cotonou, Benin

Email: ^amohermy@yahoo.fr, zoulkifls@gmail.com, gabrieldiez@anesvad.org, laryscase@yahoo.fr, rachad.lanignan@yahoo.fr, degnonvihorace@gmail.com, yvesbaro@yahoo.fr, bonigras@yahoo.fr, bokomichel@gmail.com,

rochchristianjohnson@gmail.com
\end{abstract}

How to cite this paper: Amoukpo, H., Bachirou, Z.S., Diez, G., Akuesson, L., Lanignan, R., Degnonvi, H., Barogui, Y., Boni, G., Boko, M. and Johnson, R.C. (2018) Knowledge, Attitudes and Practices of the Population of the District of Ahomadégbé (Municipality of Lalo) in Benin on Methods of Water Treatment at Home. Journal of Water Resource and Protection, 10, 251-265. https://doi.org/10.4236/jwarp.2018.103015

Received: February 3, 2018

Accepted: March 13, 2018

Published: March 16, 2018

Copyright (c) 2018 by authors and Scientific Research Publishing Inc. This work is licensed under the Creative Commons Attribution International License (CC BY 4.0).

http://creativecommons.org/licenses/by/4.0/

\section{(c) (i) Open Access}

\begin{abstract}
Water is an indispensable resource for life. In the district of Ahomadégbé in Benin, although most of the population has access to improved water sources, in their homes, residents consume poor water quality due to microbiological contamination during transport and storage. To identify necessary actions needed to improve household drinking water quality, the present study aims to analyze the knowledge, attitudes, and practices the district of Ahomadégbé's population regarding household drinking water treatments methods. A study was conducted, where 377 residents were interviewed using an individual questionnaire and 82 participants were selected for eight focus groups to determine the population's knowledge, attitudes, and practices. More than $65 \%$ of the district's population knew some methods of water treatment at home. In practice, however, they lacked the knowledge to apply the different water treatment methods and only $6.1 \%$ of the population used at least one method of water treatment at home, even if it was not always adapted. The water treatment methods residents used were Alum ( $\mathrm{KAl}\left(\mathrm{SO}_{4}\right)_{2} \cdot 12 \mathrm{H}_{2} \mathrm{O}$, chemical decantation method), filtration on tissues, and disinfection by boiling. Ineffective home water treatment methods, such as oil and cresol were also used. The population is aware of water contamination during transport and storage. Unfortunately, most residents surveyed do not treat water before consumption, and those who treat it, use inappropriate
\end{abstract}


methods. Thus, people must be made aware of the health benefits of using effective home water treatment methods and their correct use.

\section{Keywords}

KAP, Home Water Treatment Methods, Ahomadégbé, Lalo

\section{Background}

Water is a natural resource whose availability in sufficient quantity and acceptable quality contributes to the maintenance of health. Although $91 \%$ coverage of drinking water has been achieved globally, and 6.6 billion people have access to improved water sources [1], much of the world's population, especially those living in rural areas, continue to consume water of poor microbiological quality. In sub-Saharan Africa, 319 million people live without access to an improved water source and 102 million people still use surface water [1]. In Benin, water issues are still a major problem for the population, especially those living in rural areas where only $72 \%$ have access to drinking water [1].

In the municipality of Lalo, Benin, households' drinking water sources are boreholes, standpipes, modern wells, cisterns, and surface water [2]. Specifically, in the district of Ahomadégbé, household water sources are improved water sources (91.4\%) and unimproved water sources (8.6\%) [3]. Despite the district of Ahomadégbé's good coverage from improved water sources, microbiological analyses of water samples collected at the source and during transport and storage, have shown increasing microbiological contamination between source and storage [4].

More than 340,000 children under the age of 5, or almost 1000 per day, die each year from diarrheal diseases due to poor sanitation, poor hygiene, or unsafe water [1]. Diarrheal diseases are the third leading cause of death among children under 5. Despite all the progress, there is no guarantee that the population is consuming water of good microbiological quality. In rural areas, even when people have access to improved water sources, they must travel long distances before getting water. In the absence of a home piping system, access to water means water must be transported and stored at home [5] [6]. Several studies have shown that the lack of hygiene during the transport and storage of drinking water is at the root of the microbiological contamination of household water [4]-[12].

To limit water contamination, a process must be in place that includes the protection of water sources, the selection and implementation of drinking water treatment methods, and the proper management of risks in water distribution networks. Several interventions to improve the quality of drinking water are possible: source or collection point interventions, environmental interventions, and household-level interventions [13]. Household-level interventions help to 
improve water during storage, as they ensure that water quality is improved at the point of consumption [14]. Moreover, household-level interventions are twice as effective in preventing diarrhea as interventions at the source [13]. These interventions require effort from heads of household to: treat water properly, always have treated water available, avoid recontamination, and refrain from drinking untreated water [13]. Several home water treatment methods have been developed over the years and are widely used around the world. The most common are chlorination and filtration. These methods can improve the quality of drinking water and prevent disease when properly applied. Although proven effective in the laboratory, the effectiveness of these methods do depend on external factors, such as the user, the ease of use of the technology, and the levels of hygiene and sanitation [15]. Unfortunately, in rural areas the population is often insufficiently informed about home water treatment methods and therefore applies them incorrectly.

To ensure that population consumes water free from microbiological contamination in the district of Ahomadégbé, it is first necessary to establish a diagnostic process that identifies the actions to be taken. This study aims to analyze the knowledge, attitudes, and practices the district of Ahomadégbé's population regarding household drinking water treatments methods.

\section{Method}

\subsection{Study Site}

This study was conducted in the district of Ahomadégbé, which is in the municipality of Lalo, Benin (Figure 1). The municipality of Lalo is an administrative subdivision of the Couffo department and includes eleven (11) districts. The district of Ahomadégbé is subdivided into four villages, with a total population estimated at 5403 inhabitants [16].

\subsection{Description of the Study}

This is a cross-sectional study that aims to analyze knowledge, attitudes, and practices (KAP) on home water treatment methods in the district of Ahomadégbé. The study ran from April 24, 2016 to May 8, 2016.

\subsection{Sampling}

\subsubsection{Questionnaire Survey}

The questionnaires were designed to take approximately 30 minutes, including open and closed questions. The questionnaire was organized into three main sections: socio-demographic and economic characteristics; knowledge, attitudes and practices on sources of drinking water contamination; and knowledge, attitudes and practices of home water treatment methods. The questionnaire was created in French, translated into the local language Fon, and pre-tested for all translation errors. The pre-test was done before data collection in the district of Sèdjè-Dénou, municipality of Zè. 


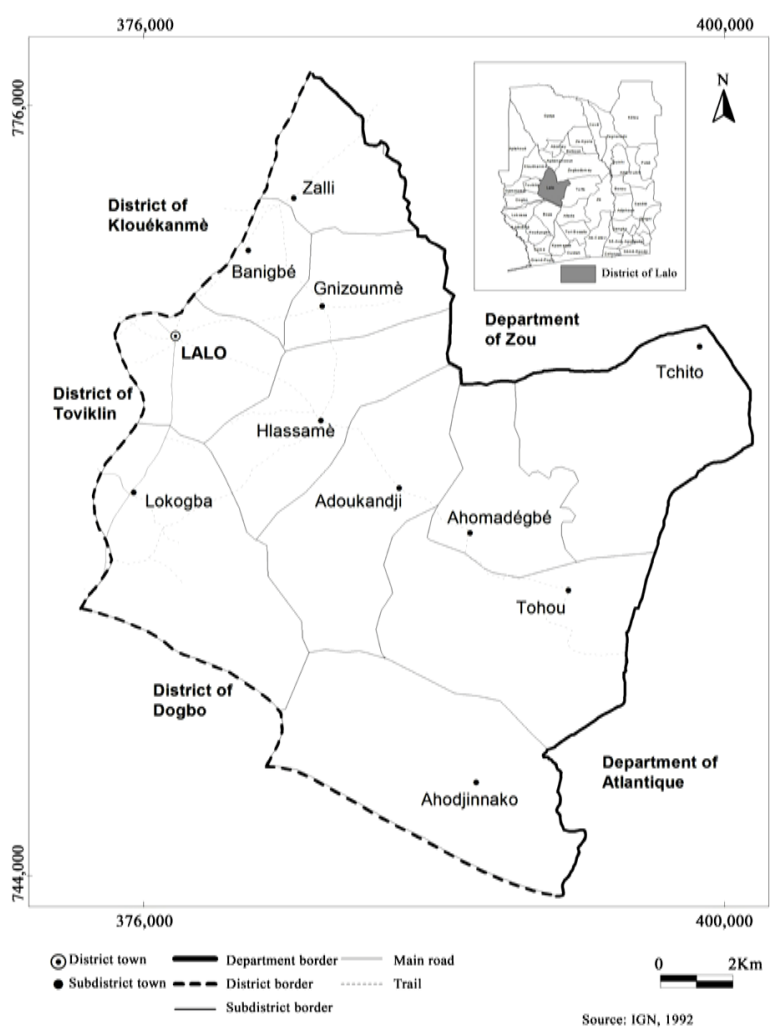

Figure 1. Location map of the municipality of Lalo, Benin.

Three hundred and seventy-seven (377) people, 342 women and 35 men residing in the villages of Ahomadégbé and Adjaïgbonou, were interviewed using an individual questionnaire.

\subsubsection{Focus Group Survey}

The venue was chosen to ensure accessibility for all, absolute neutrality, and a relaxed and quiet atmosphere. The date and time of the meeting considered the personal constraints of most participants. Each participant was contacted the day before the meeting date to ensure their presence and to answer any questions. Arrangements were also made to record all discussions.

An experienced sociologist moderated all focus groups. In addition to handwritten notes during the focus groups, the discussions were recorded and later transcribed and translated into French. All questions were open questions. The topics covered were: water and disease, the quality of water sources used for drinking, the sources of contamination of drinking water during transport and storage, and the measures to be taken to limit the contamination of water and home water treatment methods known and used in the district of Ahomadégbé. The privacy and confidentiality of the interviewees, and positive interactions between the individuals and the interviewer, were maintained during data collection.

Additionally, 82 participants were selected for eight (8) focus groups. Women and children were the main subjects for the following reasons: 
- Women are generally responsible for household water management (watering and domestic use);

- Women were helped by children in transport, and children are in more contact with the storage container either to serve themselves or to serve adults.

However, men's opinions were also gathered on the question of drinking water hygiene.

The groups consisted of a mix of water point users and managers to confront the behaviors and practices around the water points witnessed by the two subject groups. The number of participants in each focus group ranged from eight to twelve. Four (4) focus groups were conducted with women, two (2) with men, and two (2) with children (Table 1).

\section{Data Processing and Analysis}

\subsection{Data Processing}

Data processing from the questionnaire survey included:

- manual count and coding of the questionnaires;

- development of an input mask using SPSS version 19.0;

- entry of coded data; and,

- correction of any errors after data entry.

\subsection{Data Analysis}

Data was analyzed with SPSS 19.0 and EpiInfo7 software.

\subsubsection{Descriptive Aspect}

The variables were described by their size and frequency.

\subsubsection{Analytical Aspect}

We performed a bivariate analysis to investigate the association between the dichotomous qualitative dependent variable and the independent variables with adequate parametric tests. The association was considered significant for independent variables with a p-value less than 0.05 . The focus group data (the recorded discussions) were transcribed using Word 2007 software and triangulated with the data obtained through the questionnaire survey.

\subsection{Ethical Considerations}

The ethical protocol that authorized this study has been validated by the National Committee of Ethics for Health Research (No. 123/MS/DC/SGM/+DFR/

Table 1. Distribution of participants in the focus groups.

\begin{tabular}{ccccc}
\hline \multirow{2}{*}{ Villages } & \multicolumn{3}{c}{ Categories } & \multirow{2}{*}{ Total } \\
\cline { 2 - 4 } & Men & Women & Children & \\
\hline Adjaïgbonou & 12 & 23 & 12 & 47 \\
Ahomadégbé & 07 & 19 & 09 & 35 \\
Total & 19 & 42 & 21 & 82 \\
\hline
\end{tabular}


CNERS/SA). Agreement with municipality's sanitary authorities was obtained before starting data collection.

\section{Results}

\subsection{Description of Socio-Demographic and Economic Characteristics of Populations}

More than $90 \%$ of our sample is represented by women, $97.9 \%$ of which are of the Tchi ethnic group and $70 \%$ are peasants/fishermen. It should be noted that $57 \%$ of those surveyed have no education and $13.76 \%$ have a daily income of more than 500 FCFA. Socio-demographic and economic characteristics are summarized in Table 2 .

\subsection{Description of Behavioral Factors Influencing the Quality of Drinking Water}

Approximately $86.5 \%$ of the participants surveyed consume water from an improved water source, $37.9 \%$ use improved water sources for other uses, and $78.2 \%$ use the same container for water transportation water for drinking and water for other uses (Table 3). The focus groups revealed that the repeated failures of the Adjaigbonou water point are one of the main reasons for the use of water from unimproved water sources, especially rainwater. In the hamlet of Tozounmè, the population must cross the Couffo River before stocking up on an improved water source. This difficulty is also a reason why the population consumes the Couffo River water. "It is difficult for us to cross the river with the basin of water in the canoe. So, we prefer to take water directly from the river." Among residents surveyed, $70.6 \%$ estimate that the distance between the source of water and their house is between 10 and 100 meters (Table 3). In Adjaïgbonou, this is not always the case. "The pump regularly breaks down and we stay several days without water and we have to travel about $3 \mathrm{~km}$ to look for water in Ahomadégbé."

About $74.3 \%$ of the participants understand that water may be contaminated between source and storage and during storage. Most of the district Ahomadégbé's population (93.9\%) cleans the transport container before taking water (Table 3). They clean the transport container of the house: "At the pump, we have neither the time nor the space to clean the basins. When our turn comes, we must serve without waiting for others." About $26.3 \%$ of the population covers the container during the transport of drinking water. The population uses uncovered basins or cans with or without a lid for transporting drinking water. The reasons often mentioned are: "The container does not have a lid;" "The water point is near the house or in the house itself."

Regarding the coverage of the drinking water storage containers, $97.9 \%$ of respondents do so (Table 3). The population knows that" The containers (jar, plastic bucket and can) must be washed with soap before and once filled with water, they must remain closed." A minority (16.2\%) uses the drinking-water 
Table 2. Demographic and socio-economic characteristics of the respondents.

\begin{tabular}{|c|c|c|c|c|}
\hline Variables & Modalities & Frequencies & Percent \% & $95 \% \mathrm{CI}$ \\
\hline \multirow{8}{*}{ Hamlet of residence } & Yovotonou (Ahomadégbé) & 60 & 15.9 & {$[12.4-20.1]$} \\
\hline & Tozounmè (Ahomadégbé) & 60 & 15.9 & [12.4 - 20.1] \\
\hline & Towéta (Ahomadégbé) & 66 & 17.5 & {$[13.9-21.8]$} \\
\hline & Zounkpa (Ahomadégbé) & 56 & 14.9 & [11.5 - 18.9] \\
\hline & Kpanouhoué (Adjaïgbonou) & 119 & 31.6 & {$[27.0-36.6]$} \\
\hline & Hessouhoué (Adjaïgbonou) & 7 & 1.9 & {$[0.8-4.0]$} \\
\hline & Zounkpa (Adjaïgbonou) & 9 & 2.4 & {$[1.2-4.6]$} \\
\hline & Total & 377 & 100.0 & \\
\hline \multirow{4}{*}{ Sex } & Male & 35 & 9.3 & {$[6.6-12.8]$} \\
\hline & Female & 342 & 90.7 & {$[87.3-93.4]$} \\
\hline & Total & 377 & 100.0 & \\
\hline & $11-20$ & 78 & 20.7 & {$[16.8-25.2]$} \\
\hline \multirow{5}{*}{ Age } & $21-30$ & 123 & 32.6 & {$[28.0-37.6]$} \\
\hline & $31-40$ & 91 & 24.1 & {$[20.0-28.8]$} \\
\hline & $41-50$ & 62 & 16.4 & [12.9 - 20.7] \\
\hline & $51-65$ & 23 & 6.1 & {$[4.0-9.1]$} \\
\hline & Total & 377 & 100.0 & \\
\hline \multirow{4}{*}{ Marital status of the target } & Married & 275 & 72.9 & {$[68.2-77.4]$} \\
\hline & Single & 79 & 21.0 & {$[17.0-25.5]$} \\
\hline & Widower & 23 & 6.1 & {$[4.0-9.1]$} \\
\hline & Total & 377 & 100.0 & \\
\hline \multirow{3}{*}{ Ethnic group } & Tchi (Kotafon) & 369 & 97.9 & [95.7 - 99.0] \\
\hline & Adja & 8 & 2.1 & {$[1.0-4.3]$} \\
\hline & Total & 377 & 100.0 & \\
\hline \multirow{4}{*}{ School level } & Illiterate & 215 & 57.0 & {$[51.9-62.1]$} \\
\hline & Primary & 85 & 22.5 & {$[18.5-27.2]$} \\
\hline & Secondary & 77 & 20.4 & [16.5 - 24.9] \\
\hline & Total & 377 & 100.0 & \\
\hline \multirow{6}{*}{$\begin{array}{c}\text { Socio-Professional } \\
\text { Category }\end{array}$} & Farmer/Fisherman & 264 & 70.0 & {$[65.1-74.6]$} \\
\hline & Artisan & 20 & 5.3 & {$[3.4-8.2]$} \\
\hline & Trader & 13 & 3.4 & {$[1.9-6.0]$} \\
\hline & Pupil & 71 & 18.8 & {$[15.1-23.2]$} \\
\hline & Other & 9 & 2.4 & {$[1.2-4.6]$} \\
\hline & Total & 377 & 100.0 & \\
\hline \multirow{3}{*}{ Daily income } & Less than $500 \mathrm{~F}$ CFA & 90 & 23.9 & {$[19.7-28.6]$} \\
\hline & $500 \mathrm{~F} \mathrm{CFA}$ and more & 287 & 76.1 & {$[71.5-80.3]$} \\
\hline & Total & 377 & 100.0 & \\
\hline
\end{tabular}

CI: confidence interval. 
Table 3. Behavioral factors influencing the quality of drinking water.

\begin{tabular}{|c|c|c|c|c|}
\hline Variables & Modalities & Frequencies & Percent \% & $95 \% \mathrm{CI}$ \\
\hline \multirow{3}{*}{$\begin{array}{l}\text { Main sources of drinking } \\
\text { water }\end{array}$} & Improved water sources & 326 & 86.5 & {$[82.6-89.8]$} \\
\hline & Unimproved water sources & 51 & 13.5 & {$[10.3-17.5]$} \\
\hline & Total & 377 & 100.0 & \\
\hline \multirow{3}{*}{$\begin{array}{l}\text { Distance between water } \\
\text { source and houses } \\
\text { (in meters) }\end{array}$} & 10 to 100 & 266 & 70.6 & {$[65.6-75.1]$} \\
\hline & 101 to 500 & 111 & 29.4 & {$[24.9-34.4]$} \\
\hline & Total & 377 & 100.0 & \\
\hline \multirow{3}{*}{$\begin{array}{c}\text { Water sources used for } \\
\text { other uses }\end{array}$} & Improved water sources & 143 & 37.9 & {$[33.1-43.1]$} \\
\hline & Unimproved water sources & 234 & 62.1 & {$[56.9-66.9]$} \\
\hline & Total & 377 & 100.0 & \\
\hline \multirow{3}{*}{$\begin{array}{l}\text { Use of the same container } \\
\text { for the transport of } \\
\text { drinking water and water } \\
\text { for other uses }\end{array}$} & No & 82 & 21.8 & {$[17.8-26.3]$} \\
\hline & Yes & 295 & 78.2 & {$[73.7-82.3]$} \\
\hline & Total & 377 & 100.0 & \\
\hline \multirow{3}{*}{$\begin{array}{l}\text { Cleaning the container for } \\
\text { transporting drinking } \\
\text { water }\end{array}$} & No & 23 & 6.1 & {$[4.0-9.1]$} \\
\hline & Yes & 354 & 93.9 & {$[90.9-96.0]$} \\
\hline & Total & 377 & 100.0 & \\
\hline \multirow{3}{*}{ Transport container cover } & No & 278 & 73.7 & {$[69.0-78.1]$} \\
\hline & Yes & 99 & 26.3 & {$[21.9-31.1]$} \\
\hline & Total & 377 & 100.0 & \\
\hline \multirow{3}{*}{$\begin{array}{l}\text { Cleaning the storage } \\
\text { container before filling }\end{array}$} & No & 18 & 4.8 & {$[2.9-7.6]$} \\
\hline & Yes & 359 & 95.2 & {$[92.4-97.1]$} \\
\hline & Total & 377 & 100.0 & \\
\hline \multirow{3}{*}{$\begin{array}{c}\text { Cover of drinking water } \\
\text { storage } \\
\text { container }\end{array}$} & No & 8 & 2.1 & {$[1.0-4.3]$} \\
\hline & Yes & 369 & 97.9 & {$[95.7-99.0]$} \\
\hline & Total & 377 & 100.0 & \\
\hline \multirow{3}{*}{$\begin{array}{l}\text { Use of the cup for other } \\
\text { purposes }\end{array}$} & No & 316 & 83.8 & {$[79.7-87.4]$} \\
\hline & Yes & 61 & 16.2 & {$[12.7-20.4]$} \\
\hline & Total & 377 & 100.0 & \\
\hline \multirow{3}{*}{ Shelf life of drinking water } & 1 to 3 days & 254 & 67.4 & {$[62.4-72.0]$} \\
\hline & More than 3 days & 123 & 32.6 & {$[28.0-37.6]$} \\
\hline & Total & 377 & 100.0 & \\
\hline \multirow{3}{*}{$\begin{array}{l}\text { Washing hands before } \\
\text { taking water }\end{array}$} & No & 293 & 77.7 & {$[73.2-81.8]$} \\
\hline & Yes & 84 & 22.3 & {$[18.2-26.9]$} \\
\hline & Total & 377 & 100.0 & \\
\hline $\begin{array}{l}\text { Awareness of the } \\
\text { possibility of }\end{array}$ & No & 97 & 25.7 & {$[21.5-30.5]$} \\
\hline contamination of water & Yes & 280 & 74.3 & {$[69.5-78.6]$} \\
\hline $\begin{array}{l}\text { between source and storage } \\
\text { and during storage }\end{array}$ & Total & 377 & 100.0 & \\
\hline
\end{tabular}

CI: confidence interval. 
drinking cup for other purposes and $22.3 \%$ of the population washes their hands before taking drinking water in the storage container. The observation made in the field is that the same cup is used by the whole family to collect water from the storage container and then to drink. The participants know that" The water can be contaminated at the precise moment of its consumption if the cup is not clean or if the hands are dirty." More than $32.6 \%$ of the population conserves drinking water for more than 3 days. They know that:" The duration of the storage of the water must not exceed seven (7) days," and, "The water can be contaminated if it stays too much (1 week) in the bucket or jar. We must then replace it."

In conclusion, the participants surveyed are aware that the lack of hygiene can favor the contamination of water during transport and during storage. But, some behavioral factors promote microbiological contamination of water.

\subsection{Description of Home Water Treatment Methods}

According to Table 4, 65.3\% of participants have heard about home water treatment methods at least once: approximately $24 \%$ know about disinfection by boiling, 9.3\% Aquatabs tablets, $16.3 \%$ tissue filtration, $12.6 \%$ Alum $\left(\mathrm{KAl}\left(\mathrm{SO}_{4}\right)_{2} \cdot 12\right.$ $\mathrm{H}_{2} \mathrm{O}$, chemical decantation method), and $25.2 \%$ of respondents know about oil $4.1 \%$ camphor and $2 \%$ cresol. The population believes that the most effective home water treatment method is Alum. "Alum is the most effective method: as soon as you put in the water, it becomes clear."

The population knows some methods, but do not know the role or at what stage of the water treatment process each method can be used.

Table 4. Knowledge of home water treatment methods.

\begin{tabular}{ccccc}
\hline Variables & Modalities & Frequencies & Percent \% & 95\% CI \\
\hline \multirow{2}{*}{$\begin{array}{c}\text { Knowledge of home water } \\
\text { treatment methods }\end{array}$} & No & 131 & 34.7 & {$[30.0-39.8]$} \\
& Yes & 246 & 65.3 & {$[60.2-70.0]$} \\
& Total & 377 & 100.0 & \\
& Tissue filtration & 41 & 12.6 & {$[8.7-17.4]$} \\
& Disinfection by boiling & 59 & 16.3 & {$[11.9-21.5]$} \\
Known home water & Aquatabs tablets & 23 & 9.3 & {$[6.0-13.7]$} \\
treatment methods & Palm branch & 6 & 2.4 & {$[0.9-5.2]$} \\
& Lemon & 9 & 3.7 & {$[1.7-6.8]$} \\
& Oil & 62 & 25.2 & {$[19.9-31.1]$} \\
& Camphor & 10 & 4.1 & {$[2.0-7.3]$} \\
& Cresol & 5 & 2.0 & {$[0.7-4.7]$} \\
& Bleach & 1 & 0.4 & {$[0.0-2.2]$} \\
& Total & $246^{*}$ & 100.0 & \\
\hline
\end{tabular}

*Only those who claim to know the methods of water treatment at home. CI: confidence interval. 
Table 5 shows that only $6.1 \%$ of participants use at least one home water treatment method. According to the focus groups, the methods often used are: cresol, Alum, or oil." If there is cresol, we can put a little because cresol kills microbes or we can use Alum." "We put some oil inside so that it does not have any larvae in the bottom of the jar. "Other methods are sometimes used:" We also boil water or use Aquatabs, but after the water does not have a good taste." And for those who do not treat water, they mentioned the following reasons:" The water is already drinkable," "We do not know how to treat water," "We do not always have the treatment product available to us."

In practice, the participants do not know how to use these different methods of home water treatment and others use inappropriate methods.

\subsection{Factors that Significantly Influence the Implementation of Home Water Treatment Methods}

From the analysis in Table 6, it appears that only the association between knowledge of home water treatment methods and the practice of home water treatment methods (having used at least one method) is statistically significant.

\section{Discussion}

The objective of our study was to analyze the knowledge, attitudes, and practices of the population of the district of Ahomadégbé regarding methods of treating drinking water at home. Non-probability sampling was used for household selection, which allowed for a representative sample. The data was collected by a combination of techniques and tools, namely questionnaire survey and focus group. Given the language barrier, we translated the questionnaire from the French language into the local language, which could be the source of some information bias. Moreover, the inability to verify some of the participants' information could also constitute information biases.

Table 5. Attitudes and practices of home water treatment methods.

\begin{tabular}{ccccc}
\hline Variables & Modalities & Frequencies & Percent \% & 95\% CI \\
\hline \multirow{2}{*}{$\begin{array}{c}\text { Use of at least one method } \\
\text { of water treatment at home }\end{array}$} & No & 354 & 93.9 & {$[90.9-96.0]$} \\
& Yes & 23 & 6.1 & {$[4.0-9.1]$} \\
& Total & 377 & 100.0 & \\
& Alum & 6 & 26.1 & {$[10.2-48.4]$} \\
& Tissue filtration & 5 & 21.7 & {$[7.5-43.7]$} \\
Disinfection by & 6 & 26.1 & {$[10.2-48.4]$} \\
Methods of treatment & boiling & 6 & & \\
of the water used & Aquatabs tablets & 1 & 4.3 & {$[0.1-21.9]$} \\
& Oil & 3 & 13.0 & {$[2.8-33.6]$} \\
& Camphor & 2 & 8.7 & {$[1.1-28.0]$} \\
& Total & $23^{*}$ & 100.0 & \\
\hline
\end{tabular}

${ }^{\star}$ Only those who claim to use at least one method. CI: confidence interval. 
Table 6. Association between the application of home water treatment methods and socio-economic, behavioral, and environmental factors.

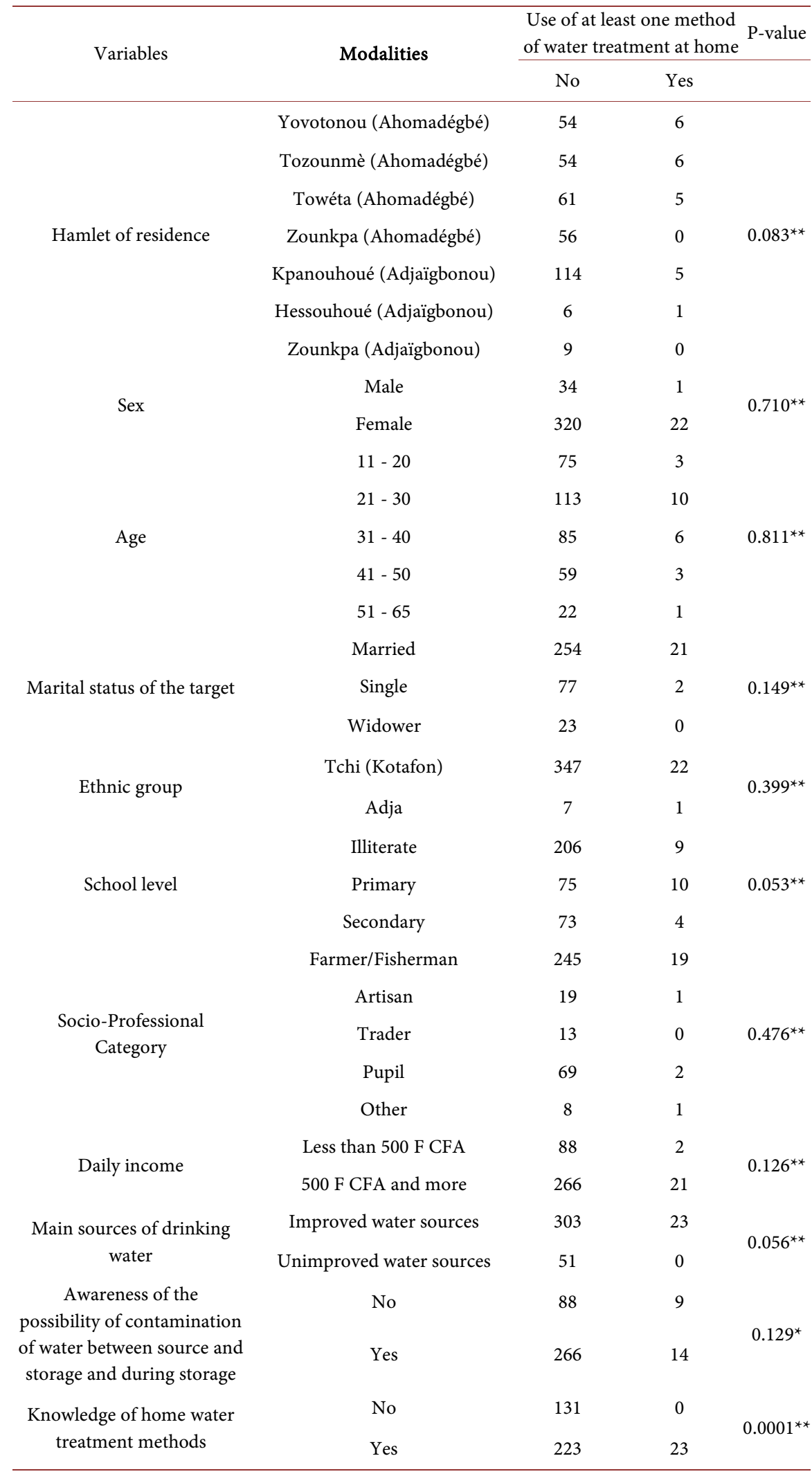

${ }^{*}$ Chi 2 test. ${ }^{* *}$ Fisher test. 
In the district of Ahomadégbé, only $37.9 \%$ of the participants use improved water sources for uses other than drinking mainly because of repeated failures of the only improved water source in the village of Adjaigbonou and the necessity of villagers to cross the Couffo River in the hamlet of Tozounmè before accessing an improved water source .Distance is therefore a factor that determines the choice of water source used for drinking and for other uses in this borough. The easy access to a water source is assessed in relation to the distance between the residence and the supply point, and the time set to get water [17]. Overall, when Adjaïgbonou's supply point is operating, all participants have access to an improved source within 1000 meters. These results are similar to Kouakou et al.'s study of Abidjan, where they found that water sources were all located less than one kilometer from the households, guaranteeing basic access to the distance criterion for access to water [18]. In the district of Ahomadégbé, more than 62\% use unimproved water sources for other uses although $70.6 \%$ obtain their water from a source located within 100 meters of their home. Howard and Bartram argued that when the distance between the water source and the house is less than 100 meters from the residence, all aspects of personal hygiene are assured [19]. Yet, when the distance between the water source and the residence is between 100 meters and 1000 meters, hand washing and basic hygiene are possible, but showering and laundry are difficult to ensure unless they are done at the source [19].

Nearly $98 \%$ of the population covers storage containers for drinking water. In Ahomadégbé, $67.4 \%$ of the population retains drinking water for one to three days. This result is different from that of Lalanne. In the province of Ganzourgou in Burkina Faso, 25\% of the population gets their supplies twice a day and $75 \%$ collect water once a day [6].

In terms of knowledge of home water treatment methods, $65.3 \%$ of the population is familiar with home water treatment methods. This result is superior to that of Lalanne, who found that $48 \%$ of participants have knowledge of home water treatment methods [6]. The methods known by the district of Ahomadégbé population are among others: Alum, tissue filtration, boiling disinfection, Aquatabs tablets, palm branch, lemon, oil, camphor, and cresol. However, the population believes that the most effective home water treatment method is Alum. There is confusion between sedimentation and water disinfection because the use of Alum accelerates the sedimentation process. For effective water treatment, the following three physical and microbiological processes must be complementary: sedimentation, filtration, and disinfection [20]. Participants know good and bad methods, and do not know at what stage of the water treatment process the right methods should be used.

In practice, $93.9 \%$ of the population does not treat drinking water. In the province of Ganzourgou, $90 \%$ of the participants do not treat the water before its consumption because the boreholes are of good water quality and thus treatment is unnecessary [6]. Joshi et al. found that the supposed potability of water, the 
high cost of the methods, and the ignorance of these methods are reasons for not treating water before its consumption [21]. In the district of Ahomadégbé, 6.1\% of the population uses at least one treatment method. In the peri-urban zone in Abidjan, 3\% of the population treats water [18]. Yet, Ndiaye et al. found that in $79 \%$ of cases studied drinking water was treated in Senegalese rural areas. [22]. In the district of Ahomadégbé, those who treat drinking water primarily use it as a method that is non-detrimental method to their health: Alum, tissue filtration, boiling disinfection, but these methods are used incorrectly. Each household uses one or the other method. A survey in Benin showed that few households treat drinking water even if the water source is not improved [23]. And, most of the time they do not use treatment methods according to the recommended procedures [23].

Methods like cresol, camphor, and oil are also used. These results corroborate those of Akowanou et al. who found that in the Mono and Couffo departments, people use oil and crushed palm leaves as home water treatment methods [23]. If these methods prevent the emergence and multiplication of larvae, they are dangerous to human health because they cause chemical contamination of the water.

In general, the most common home water treatment methods used in rural Benin are boiling, adding chlorine, filtration (tissue, ceramic filter or some other filter), and solar disinfection [24]. Yelognissè's work reveals that in rural Benin some women use white tissues for filtration and Alum, while other women use boiling or decantation of water as endogenous methods of drinking water treatment [25]. In the state of Katsina in Nigeria, tissue filtration is the most used method, followed by boiling and adding chlorine [11]. In India, a study has shown that people use filtration and boiling as water treatment methods [21]. Generally, in developing countries boiling, filtration, or chlorination are effective for improving the microbiological quality of drinking water [26]. But in the district of Ahomadégbé, the population prefers Alum, which represents one of the phases for the effective treatment of drinking water. The study of factors influencing the application of home water treatment methods revealed an association between knowledge of home water treatment methods and the application of those methods. For better implementation of home water treatment methods, it is necessary to bring the knowledge to the people through various awareness programs, whether in the community, schools, or health centers, or in educational or learning centers.

\section{Conclusion}

Our study of the knowledge, attitudes, and practices of the population in the district of Ahomadégbé regarding home water treatment methods revealed that the population is aware of water contamination during transportation and storage. Unfortunately, only $6.1 \%$ of the participants surveyed use at least one water treatment method, but use water treatment methods improperly. This study provides basic information for any intervention to improve the quality of home 
water in this district.

\section{Acknowledgements}

We are very grateful to the people of the district of Lalo and the CDTUB health professionals. We are thankful to the Anesvad Foundation for partially supporting the field work.

\section{Conflict of Interests}

The authors declare that they have no competing interests.

\section{References}

[1] OMS/UNICEF (2015) Progress on Sanitation and Drinking Water. OMS. p. 90.

[2] Johnson, R.C., Boni, G., Barogui, Y., Sopoh, G.E., Houndonougbo, M., Anagonou, E., et al. (2015) Assessment of Water, Sanitation, and Hygiene Practices and Associated Factors in a Buruli ulcer Endemic District in Benin (West Africa). BMC Public Health, 15, 801. https://doi.org/10.1186/s12889-015-2154-y

[3] Amoukpo, H. (2015) Facteurs associés à la qualité de l'eau de boisson dans l'arrondissement d'Ahomadégbé, commune de Lalo (République du Bénin) en 2015. CIFRED/UAC, Mémoire Master, Cotonou.

[4] Johnson, R.C., Boni, G., Amoukpo, H., Barogui, Y., Diez, G., Agossadou, D., et al. (2016) Microbiological Quality Assessment of Drinking Water in Lalo Commune, Benin (West Africa). Journal of Water Resource and Protection, 8, 816-822. https://doi.org/10.4236/jwarp.2016.88066

[5] BMZ, IOB (2011) Évaluation d'impact des programmes d'approvisionnement en eau potable et d'assainissement au Bénin: Le risque d'effets éphémères. La Haye, Pays-Bas: BMZ (Ministère fédéral allemand pour la coopération et le développement économiques) et IOB (Inspectie Ontwikkelingssamenwerking en Beleidsevaluatie (Service néerlandais de l'évaluation des politiques et des opérations)). p. 218.

[6] Lalanne, F. (2012) Etude de la qualité de l'eau le long de la chaîne d'approvisionnement au niveau des consommateurs dans 10 villages de la Province du Ganzourgou, (Région du Plateau Central, Burkina Faso). Fondation 2iE et UNICEF. p. 70.

[7] Dikassa, L., Mock, N., Magnani, R., Rice, J., Abdoh, A., Mercer, D., et al. (1993) Maternal Behavioural Risk Factors for Severe Childhood Diarrhoeal Disease in Kinshasa. International Journal of Epidemiology, 22, 327-333.

[8] Gentilini, M. and Viens, P. (1993) Tropical Communicable Diseases. Eurotext, Paris, $132 \mathrm{p}$.

[9] Gil, A., Lanata, C., Kleinau, E. and Penny, M. (2004) Children's Feces Disposal Practices in Developing Countries and Interventions to Prevent Diarrheal Diseases. A Literature Review. Environmental Health Project, US Agency for International Development, Washington DC, p. 67.

[10] Judah, G., Donachie, P., Cobb, E., Schmidt, W., Holland, M. and Curtis, V. (2009) Dirty Hands: Bacteria of Faecal Origin on Commuter's Hands. Epidemiology and Infection, 138, 409-414. https://doi.org/10.1017/S0950268809990641

[11] Onabolu, B., Jimoh, O.D., Igboro, S.B., Sridhar, M.K.C., Onyilo, G. and Ilya, R. (2011) Source to Point of Use Drinking Water Changes and Knowledge, Attitude and Practices in Katsina State, Northern Nigeria. Physics and Chemistry of the Earth, 36, 1189-1196. https://doi.org/10.1016/j.pce.2011.07.038 
[12] Johnson, R.C., Segla, H., Dougnon, T.V., Boni, G., Bankole, H.S., Houssou, C., et al. (2014) Situation of Water, Hygiene and Sanitation in a Peri-Urban Area in Benin, West Africa: The Case of Sèmè-Podji. Journal of Environmental Protection, 5, 1277-1283. https://doi.org/10.4236/jep.2014.512121

[13] Clasen, T., Schmidt, W.P., Rabie, T., Roberts, I. and Cairncross, S. (2007) Interventions to Improve Water Quality for Preventing Diarrhoea: Systematic Review and Meta-Analysis. BMJ, 334, 782. https://doi.org/10.1136/bmj.39118.489931.BE

[14] Ehdaie, B., Rento, C.T., Son, V., Turner, S.S., Samie, A., Dillingham, R.A., et al. (2017) Evaluation of a Silver-Embedded Ceramic Tablet as a Primary and Secondary Point-of-Use Water Purification Technology in Limpopo Province, S. Africa. PloS One, 12, e0169502. https://doi.org/10.1371/journal.pone.0169502

[15] Dreibelbis, R., Winch, P.J., Leontsini, E., Hulland, K.R., Ram, P.K., Unicomb, L., et al. (2013) The Integrated Behavioural Model for Water, Sanitation, and Hygiene: A Systematic Review of Behavioural Models and a Framework for Designing and Evaluating Behaviour Change Interventions in Infrastructure-Restricted Settings. BMC Public Health, 13, 1015. https://doi.org/10.1186/1471-2458-13-1015

[16] INSAE (2016) Effectifs de la population des villages et quartiers de ville du Bénin (RGPH-4, 2013). Institut Nationalde la Statistiqueet de L'Analyse Economique, Cotonou, p. 85.

[17] Koukougnon, W.G. (2012) Stratégies d'accès à l'eau potable dans un quartier défavorisé: cas de Gobelet dans la commune de Cocody (Abidjan-Côte d'Ivoire). Canadian Journal of Tropical Geography, 2, 60-72.

[18] Kouakou, J.G.S., Oga, S., Claon, S., Bama, M., Koua, D.M., Houénou, Y., et al. (2010) Conditions d'accès et de stockage de l'eau: Enquête dans les ménages en zone périurbaine à Abidjan en 2010. Santé Publique, 24, 133-142. https://doi.org/10.3917/spub.122.0133

[19] Howard, G. and Bartram, J. (2003) Domestic Water Quantity, Service, Level and Health. OMS, p. 39.

[20] pS-Eau (2012) Conservation et traitement de l'eau à domicile. pS-Eau, Paris, p. 37.

[21] Joshi, A., Prasad, S., Kasav, J.B., Segan, M. and Singh, A.K. (2014) Water and Sanitation Hygiene Knowledge Attitude Practice in Urban Slum Settings. Global Journal of Health Science, 6, 23-34.

[22] Ndiaye, P., Ba, I.O., Dieng, M., Fall, C. and Dia, A.T. (2010) Qualité de l'eau de consommation des ménages: Analyse et plan d'action en zone rurale sénégalaise. Santé Publique, 22, 193-200. https://doi.org/10.3917/spub.102.0193

[23] Akowanou, A.V.O., Aina, M.P., Groendijk, L. and Yao, B.K. (2016) Household Water Treatment in Benin: Current/Local Practices. European Journal of Scientific Research, 142, 246-256.

[24] INSAE (2013) Enquête Démographique et de Santé du Bénin (EDSB-IV) 2011-2012. Ministère du Développement, de l'Analyse Économique et de la Prospective, Institut National de la Statistique et de l'Analyse Économique (INSAE), Cotonou, ICF International Calverton, Maryland, p. 573.

[25] Yélognissè CLHH (2007) L'amélioration des conditions d'accès à une eau potable pour l'eau de boisson dans les milieux ruraux du Bénin: étude des pratiques locales. Mémoire de Maîtrise en Science de l'environnement, Québec: UNIVERSITÉ DU QUÉBEC, MONTRÉAL.

[26] Clasen, T. (2015) Household Water Treatment and Safe Storage to Prevent Diarrheal Disease in Developing Countries. Current Environmental Health Reports, 2, 69-74. https://doi.org/10.1007/s40572-014-0033-9 